\title{
Improving Hospital Financial Performance: Application of Social Responsibility Future Research
}

\author{
Ali Azhdari (iD) Mahmoud Moeinaddin ${ }^{2 *}$ (D) Forough Heirani ${ }^{3}$ (iD) Shahnaz Nayebzadeh 4 (ID) \\ Abstract
}

Introduction: Today, managers in the field of health and care, especially in hospitals, need to address not only the internal issues but also the social and environmental issues of their decisions and actions to improve financial performance and increase productivity. The purpose of this study was to improve the financial performance of hospitals through social responsibility future study.

Methods: The method of this research was applied in terms of purpose, and according to the research methodology, it was a mix of quantitative and qualitative methodology consisting of phenomenology, content analysis, and future study. In the first step, phenomenological methods and interviews with experts were used to extract hospital financial performance indicators. In the second step, the content analysis method and systematic review on selected articles, dimensions, and indicators of social responsibility were extracted. Finally, as for the future study, the variables related to social responsibility were extracted through fuzzy delphi technique and analyzed using structural-interpretive model.

Findings:In the first step, 16 financial performance indicators were extracted. In the second step, the results of this phase showed the extraction of 35 proponents and four dimensions of economic, social, employee, and environmental social responsibility. In the last step, 20 variables related to social responsibility were extracted using the structural-interpretive model. The power of penetration and the degree of the dependence of the variables were determined.

Conclusion: The research results showed that all the variables associated with social responsibility had a great deal of influence and instability powers. That is, any change that occurs on them affects both them as well as other variables. Since the main purpose of public hospitals is to provide quality services to all segments of society and satisfy them, Therefore, considering all dimensions and components of social responsibility increases productivity and consequently improves the financial performance of hospitals.

Keywords: financial performance, social responsibility, future study, hospitals, proponents

- Received: 09/Jan/2020 • Modified: 07/March/2020 • Accepted: 16/March/2020

\footnotetext{
${ }^{1}$.PHD Student of Accounting, Faculty of Accounting, Yazd Branch, Islamic Azad University, Yazd, Iran , (ajdary58@gmail.com)

2 .Assistant Professor of Accounting Department, Yazd Branch, Islamic Azad University, Yazd, Iran; Corresponding author, (mahmoudmoein@iauyazd.ac.ir)

3 .Assistant Professor of Accounting Department, Faculty of Accounting, Yazd Branch, Islamic Azad University, Yazd, Iran, (heyrani@iauyazd.ac.ir)

4. Assistant Professor of Department of Management, Yazd Branch, Islamic Azad University, Yazd, Iran ,

(snayebzadeh@iauyazd.ac.ir)
} 


\title{
رابطه فرهنَ ايمنى بيمار و حوادث ناخواسته در بيمارستان: مطالعه موردى
}

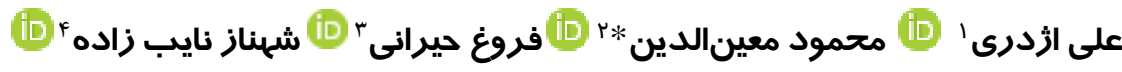

جكيده

مقدمه: امروزه مديران در حوزه بهداشت و درمان بهويزه بيمارستانها براى بهبود عملكرد مالى و افزايش بهرهورى نهتنها بايد به مسائل درونى توجه كنتد بلكه مسائل اجتماعى و زيستمحيطى را نيز بايد سرلوحه همه تصميمات و اقدامات خود قرار دهند. هدف

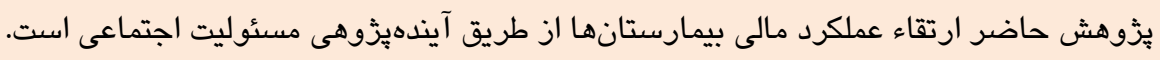
روشها: بِزوهش حاضر ازنظر هدف كاربردى بوده و برحسب روش بِّوهش، آميخته كيفى و كمى است كه در سه مرحله اجرا شد. در مرحله اول با براى استخراج شاخصهاى عملكرد مالى بيمارستان از روش بديدارشناسى و مصاحبه با خبركان استفاده كرديد. در مرحله دوم با روش تحليل محتواو مرور نظاممند بر روى مقالات منتخب، ابعاد و شاخصهاى مسئوليت اجتماعى استخراج شد و در

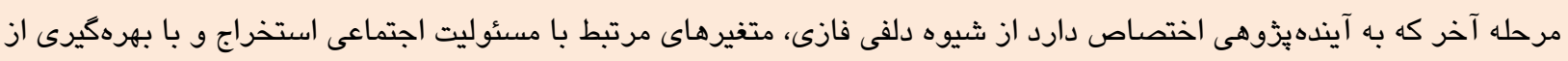
مدل ساختارى - تفسيرى اين متغيرها تحليل شد. يافتهها: در مرحله اول تعداد 17 شاخص عملكرد مالى استخراج شد. حاصل مرحله دوم، تعداد ب متغير و جهار بعد اقتصادى، اجتماعى، كاركنان و محيطزيست براى مسئوليت اجتماعى بود و در مرحله آخر تعداد ·r متغير مرتبط با مسئوليت اجتماعى استخراج و با بهرهكيرى از مدل ساختارى - تفسيرى، قدرت نفوذ و ميزان وابستكى متغيرها تعيين كرديد. نتيجه گيرى: تمام متغيرهاى مرتبط با مسئوليت اجتماعى داراى قدرت نفوذ و وابستكى زيادى (بىثباتى) هستند. بدين معنا كه تغيير

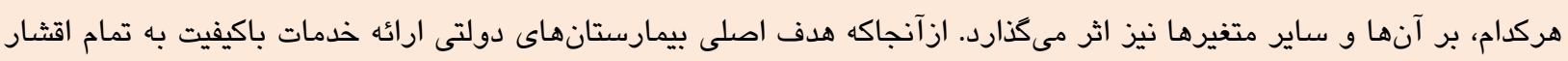

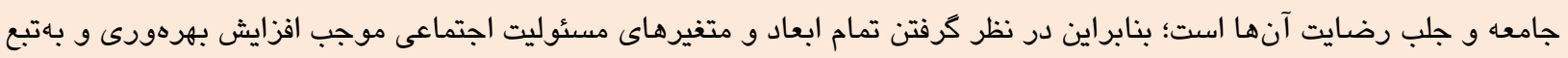

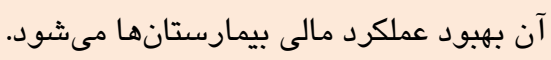
وازمهاى كليدى: عملكرد مالى، مسئوليت اجتماعى، آيندهيزوهى، بيمارستانها، بيشرانها.

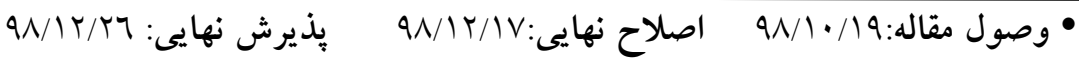

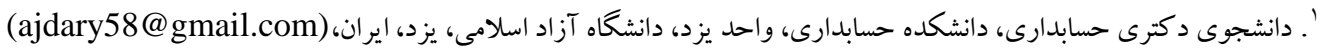

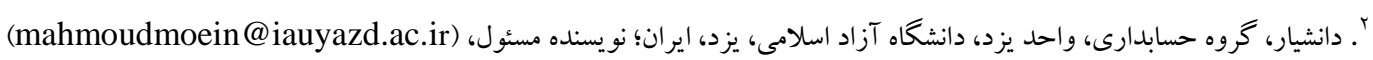

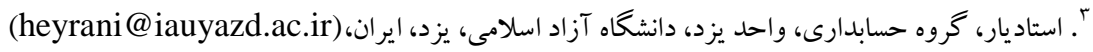

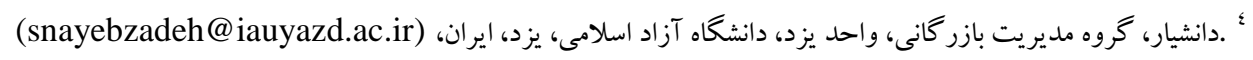


رضايت بيماران و نظرات آنها در مورد خدمات بيمارستانى، به دليل رقابتهاى درمانى بيمارستان و يذيرش بيشتر بيمار در جهت كاهش هزينهاى درمانى و بالطبع افزايش درآمد بيمارستانها يكى از متداولترين روشها و وارزيابى خدمات بيمارستانى بوده و نتيجه آن بهطور گستردهاى در خدمات

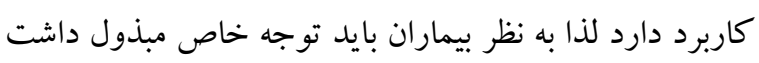

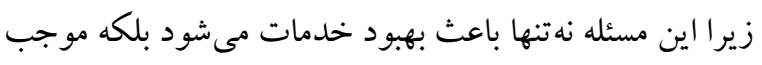
اصلاحات در ارائه خدمات و اجراى آن مطابق استانداردها

$$
\text { خو اهد شد. [F] }
$$

از سوى ديخر نظام اقتصادى و مالى در بيمارستانها وابسته به وجود بخش مالى كارا و قدرتمند است. امروزه بسيارى از بيمارستانها بهويزه بيمارستانهاى آموزشى و دولتى با مشكل نداشتن كفايت درآمدهاى بيمارستانى براى تأمين هزينههاى

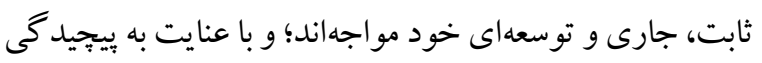
فر آيندهاى موجود در نظام هزينه و در آمد بيمارستانها، مداخله روساى بيمارستانها درصورتى كه از الكوهاى علمى تبعيت ننمايند، نخواهند تو انست منجر به بهبود در فر آيندهاى اقتصادى ليماري بيمارستانها و رضايت مشتريان شود. [ه] بنابراين ارزيابى و بهبود عملكرد مالى دوروى يكك سكه مىباشند كه اقدام براى اولى، منجر به تغيير در دومى خواهد شد. در كذشته عملكرد

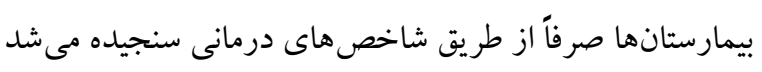
درحالى كه بيجيدگ هزينه هاى فزاينده بهداشت و درمان، تخصص گرايى، تأكيد بر مشترى، محيطزيست، جامعه و همجنين كارايى و اثربخشى خدمات ازجمله عواملى هستند كه بيمارستانها را به تحول در ارزيابى عملكرد بهويزه عملكرد مالى ترغيب و تشويق نموده

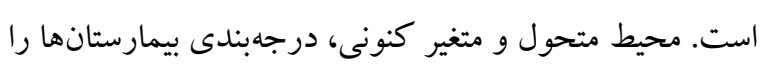
به لحاظ اعتبارى نيز تا حدودى به ساختار مالى آنان منوط كرده [4]

\section{مقدمه}

امروزه كنترل روند فزاينده هزينهاى نظام سلامت جزء دغدغه هاى اساسى دولت ها است ـ محدوديت هاى بودجهاى در بخش دولتى، توزيع برابر منابع بين خدمت كيرند كان بدون توجه به عدالت عمومى و درصد بالاتر ويرداخت از جيب دهككاى يايين درآمدى، عدم كارايى بخش دولتى و يايين بودن سطح كيفيت خدمات موجب شد تا سياست گذاران به دنبال راهحلى براى بهبود وضعيت ارائه خدمات در بخش دولتى باشند. بهرهورى يايين بيمارستانهاى دولتى و سرانه يايين تخت هاى بيمارستانى ازجمله نمونه هاى ضعف خدمترسانى در مر اقبت هاى بسترى ايران هستند. [1] با توجه به اين كه بيشرفتهاى فن آورانه، رشد انتظارات مشتريان، افزايش تقاضا، كمبود منابع و نخرانى در مورد خطاهاى سيستمهاى بهداشتى درمانى، بر بيجِيدگى بيشتر نظام هاى بهداشتى درمانى افزودهاند، اين امر موجب شده تابر مسئله عملكرد سازمانهاى بهداشتى درمانى تأكيد شود. آماروشاخص ها، معيارى جهت اندازه گيرى موفقيت عملكرد سازمان هستند و ميزان وصول به اهداف موردنظر آن سازمان را تعيين مى كند. بنابراين، اعمال نظارت به نحوموثر، نيازمند تهيه و به كاركيرى

$$
\text { شاخص هاى مناسب است. [Y] }
$$
بيمارستانها مهمترين و برهزينهترين اجزاى سيستمهاى بهداشتى درمانى هستند. آنها بيش از دوسوم هزينهاى بهداشتى رابه خود اختصاص مىدهند و بهطور جشمكيرى روى كيفيت كلى مراقبتهاى بهداشتى درمانى تأثير مى گذارند. از آنجاكه رقابت در بين بيمارستانها جهت جلب رضايت بيشتر بيمار و كاهش هزينه هاى درمانى و درنهايت افزايش درآمد بيشتر منجر به تغييرات اساسى در ساختار و عملكرد بيمارستانها در سالهاى اخير شده است، لذا ارزشيابى ديدكاه و نظرات بيماران از جايگاه ويزهاى برخوردار است. [س] بنابر اين، بررسى 
بهخصوص بيمارستانها مطالعات اندكى انجامشده است و مطالعات اندك انجامشده درزمينه مسئوليت اجتماعى بيمارستانها جهت دستيابى به مبنايى براى تدوين الخوى مسئوليتيذيرى بيمارستانها بوده است. [1/] : بزوهشهاى كذشته مبين آن است كه مسئوليت اجتماعى در بهبود كيفيت و ارائه خدمات مناسب در تمام سازمانها بهويزه بيمارستانها كه ارائه كنندگان خدمات به عموم جامعه هستند نقش مؤثرى را ايفا مى كند. با توجه به اهميت رعايت مسئوليت اجتماعى در بهبود عملكرد مالى، هدف از انجام يزٔوهش حاضر، ارتقاء عملكرد مالى آتى بيمارستانهاى دولتى با استفاده از ابعاد و مؤلفه هاى مسئوليت اجتماعى است.

\section{روشها}

روش انجام يزوهش حاضر بر اساس بياز يزوهش [If] مبتنى بر يار ادايم تفسيرى بوده و به لحاظ جهت گيرى، از يككسو بنيادى بوده، زير ابه دنبال يافتن شاخصهاى عملكرد مالى بيمارستانها و ابعاد مسئوليت اجتماعى در اين حوزه است و از سوى ديخر كاربردى است زيرابه صورت كاربردى مىتوان با به كار كيرى نتايج حاصل از مطالعه، آينده مطلوب عملكرد مالى بيمارستانها را از طريق پيايبندى بيشتر بيمارستانها به مسئوليت اجتماعى ترسيم نمود. رويكرد يثزوهش استقرايى است زيرا از جزء به كل مىرسد و صبغهُ آن كيفى است. هدف از انجام يثوهش حاضر اكتشافى است كه بهصورت تكك مقطعى انجام مى يذيرد. محيط "يخوهش، ميدانى و استراتزى آن آيندهيزوهى است.
اهميت مسئوليت اجتماعى و نقش آن در بهبود عملكرد مالى بيمارستانها در يزوهشهاى زيادى انعكاس يافته است. جعفريان و همكاران [V] در يزؤهش خود بيان نمودند كه در سالهاى اخير، علاقه عمومى به شفافيت نهادها در حوزه مسئوليت اجتماعى به ميزان قابلتوجهى افزايشيافته است؛ به كونهاى كه حوزه سلامت و بهخصوص بيمارستانها نيز از اين قاعده مستثنى نبوده و مى توانند از يذيرش مسئوليت اجتماعى بهرهمند شوند. درويرت و همكاران [A] در مقاله خود نشان دادند كه در حال حاضر، مسئوليت اجتماعى سازمانها بهعنوان يكك موضوع حياتى و نيازمند توجه در بيمارستانها مطرحشده است؛ و با توجه به اينكه بيمارستانها تأثير عمدهاى بر جامعه دارند، بنابراين، فعاليت آنها بايد به گونهاى باشد كه اثرات مثبت حاصل از فعاليت خود را به حداكثر و اثرات منفى رابه حداقل برسانند. قاسم نزاد و همكاران [9] نيز موفقيت مديران در بيمارستانها را نهتها منوط به توجه آنها به محيط داخل بيمارستان كه مستلزم در نظر داشتن محيط بيرونى آن دانستند كه اين همان يذيرش مسئوليت اجتماعى توسط بيمارستان است. مكك دانيل و همكاران [•][ بيان كردند كه بيمارستانها براى دستيابى به موفقيت، بايد در كنار توجه به هدف افزايش بهرهورى، به انتظارات اجتماعى و احكام اخلاقى، واكنش مناسب نشان دهند و با رعايت مسائل اجتماعى از قبيل كاهش زبالههاى غذايى در حمايت از محيطزيست و ايجاد رزيمهاى بايدار نقش مهمى را در حمايت از بهداشت عمومى در جامعه انجام دهند. لوبيس و همكاران [11] نيز موفقيت بيمارستانها را در دستيابى به شهرت سازمانى و افزايش اعتماد عمومى و بهتبع آن توانايى رقابت با سازمانهاى ديخر را در شناخت بهتر از انتظارات و توقعات جامعه و فرصتهاى مرتبط با مسئوليت

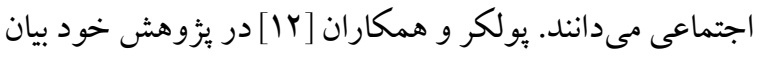
كردند كه درزمينه مسئوليت اجتماعى حوزه سلامت و 


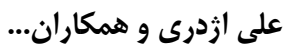

آيندهيزوهى اختصاص دارد و جهت ترسيم آينده مطلوب

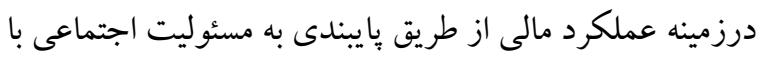
استفاده از شيوه دلفى تعداد ·. متغير مر تبط با مسئوليت اجتماعى استخراج و درنهايت و براى تعيين قدرت نفوذ و وابستكى هر يك از متغيرهاى مستخرج از تكنيك دلفى از مدل ساختارى تفسيرى(Interpretive Structure Modeling(ISM) به شرح زير استفادهشه است. قبل از اجراى مدل ساختارى - تفسيرى و بهمنظور تسهيل در اجراى مدل، براى هر يكك از متغيرهاى مسئوليت اجتماعى نمادهايى به شرح جدول يكك در نظر گرفتهشد.

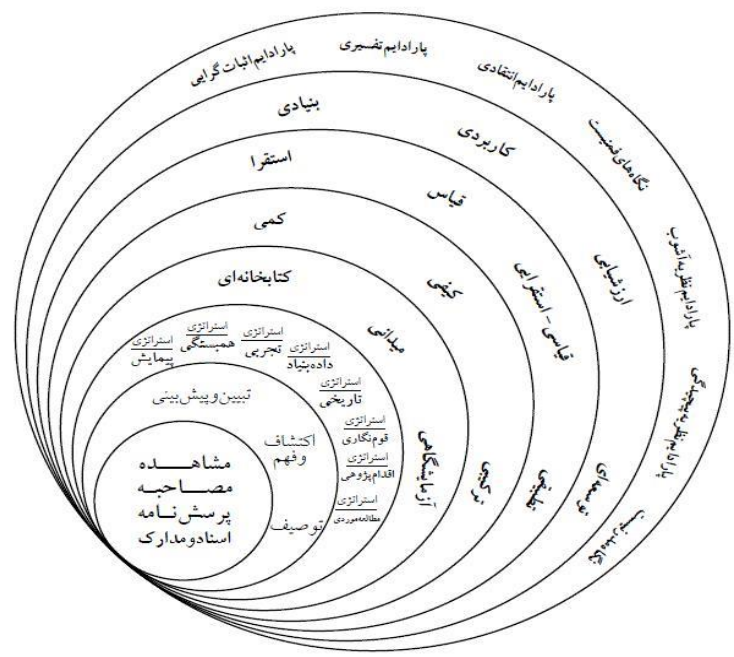

شكل ا: يِياز فرآيند يُّوهش [IF]

يزوهش حاضر بهمنظور دستيابى به اهداف خود مراحل زير را

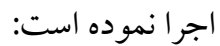
در مرحله اول يزّوهش و براى تعيين شاخصهاى عملكرد مالى لي در بيمارستانهاى دولتى از روش پديدارشناسى استفادهده است. شيوه گردآورى دادهها از طريق مصاحبه نيمه ساختاريافته و نيمه عميق و شيوه تحليل دادهها با استفاده از كد گذارى باز و محورى و با استفاده از نرم|فزار 8tlas.ti.8 انجام كرفته است كه تعداد 19 شاخص از متن مصاحبه ها استخراج گرديد. مرحله دوم تحقيق مرتبط با تعيين و شناسايى شاخصها و ابعاد مسئوليت اجتماعى در بيمارستانهاى دولتى است كه براى اين

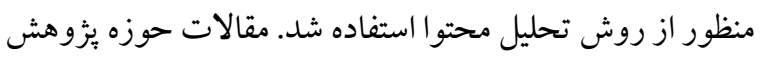
با استفاده از روش مرور نظاممند و نرمافزار VOS viewer تعيين و ارزيابى گرديد. شيوه تحليل دادهها با استفاده از

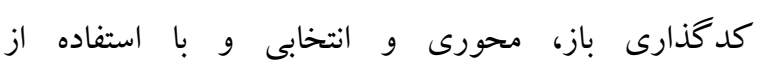
نرم|فزار Atlas.ti.8 انجام كرفته است كه تعداد ذه متغير مرتبط با مسئوليت اجتماعى استخراج شد. مرحله سوم به ترسيم آينده مسئوليت اجتماعى بيمارستانى در

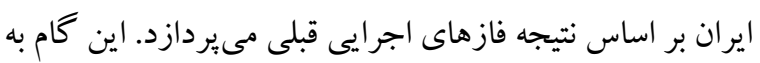


جندين بار در هفته و هرروز) تقسيم شد. از طريت تعديل ساير متغيرها (سن، جنس، وضعيت تأهل، سطح تحصيلات، سابقه كار، بخش محل كار، ميز ان ساعت كارى در هفته) در مدل رگرسيون، اثر مخدوش كرى آنها كنترل شد.

\section{يافته ها}

يافتهاى جمعيت شناختى

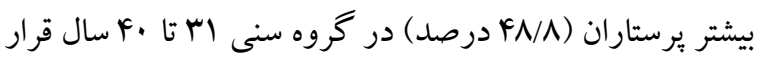
داشتند. بيشتر آنها زن (VN/9 درصد) و مجرد (V//Y درصد) بودند. از طرف ديخر بيشتر شر كت كنند كان سابقه زير ·. سال (درصد داشتند و داراى مدرك تحصيلى كارشناسى VN/q) (19/Y درصد) بودند. هم:جنين، بيشتر آنها در بخشهاى عمومى بيمارستان مشغول به كار بودند (FF/9 درصد) و بيش از

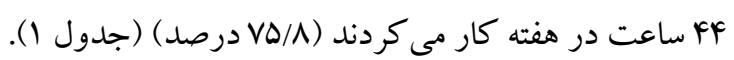

\section{كام هاى اجراى مدل ساختارى - تفسيرى} كام اول: شناسايى متغيرهاى مرتبط با مسئله: براى استخراج متغير هاى مربوط به موضوع مسئوليت اجتماعى از مطالعات r. كسترده ادبيات وروش تحليل محتوا استفاده شد و درنهايت متغير كليدى مرتبط توسط خبر كان تأييد نهايى گرديد.بار در ماه، F= يككبار در هفته، ه= جندين بار در هفته، 9- هرروز) درجهبندى شده است. همه دادهها بهوسيله نرمافزار SPSS نسخه YY تحليل شد. نتايج توصيفى مرتبط بافرهنگ ايمنى بيمار، حوادث نامطلوب و

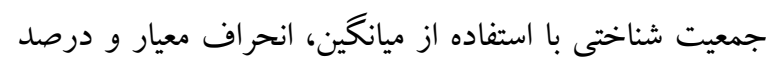
ارائهشه است. بهمنظور بررسى رابطه بين سطح فرهنگك ايمنى

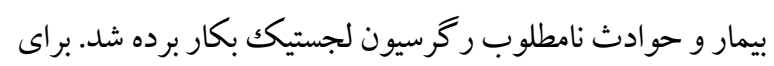
اين منظور شش حادثه نامطلوب به دو گرووه صفر= هر زز حادثه اتفاق رخ نداده است و يكك=اتفاق رخداده است (از قبيل جندين بار در سال، يككبار در ماه، جندين بار در ماه، يككبار در هفته،

جدول ا: توزيع فراوانى يرستاران شركت كننده در مطالعه بر اساس متغيرهاى جمعيت شناختى

\begin{tabular}{|c|c|c|c|}
\hline درصد & تعداد & \multicolumn{2}{|c|}{ متغير } \\
\hline$F r / 9$ & rW & $r \mid-r$. & \multirow{3}{*}{ سن (سال) } \\
\hline FN/A & MIV & rI-r. & \\
\hline N/9 & $\Delta q$ & $\geq+1$ & \\
\hline YM/l & IrV & مرد & \multirow{2}{*}{ جنس } \\
\hline$V N / 9$ & DIr & 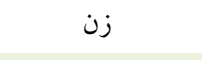 & \\
\hline$V I / r$ & kar & 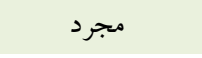 & \multirow{2}{*}{ وضعيت تأهل } \\
\hline YN/A & IVA & 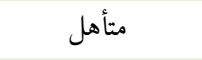 & \\
\hline$V N / 9$ & Dir & $<1$ & \multirow{2}{*}{ سابقه كار بالينى (سال) } \\
\hline$r y / l$ & IrV & $\geq 1$ & \\
\hline$\Lambda 9 / r$ & $\Delta q$. & كارشناسى & \multirow{2}{*}{ سطح تحصيلات } \\
\hline $\mid r / \Lambda$ & 9. & كارشناسى ارشد & \\
\hline$r F /$. & rYI & مر اقبتهاى ويزه & \multirow{3}{*}{ بخش محل كار } \\
\hline YM/l & ITV & اورزانس & \\
\hline$F F / q$ & rar & بخش هاى عمومى & \\
\hline$V \Delta / \Lambda$ & pqu & ساعت fr & ميزان ساعت كارى در \\
\hline$T F / Y$ & $1 \Delta V$ & 1 & هفته \\
\hline $1 \ldots$ & 90. & & 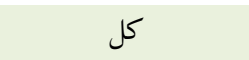 \\
\hline
\end{tabular}




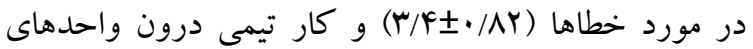

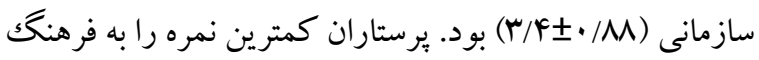

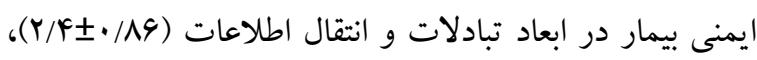
حمايت مديريت از ايمنى بيمار (190/9 • (Y/90) و باز بودن مجارى

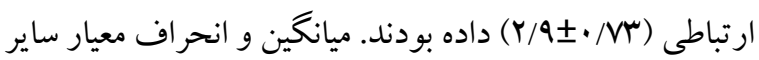
ابعاد در جدول دو ارائه شده است.

\section{ميانگين نمر ات ابعاد فر هنگك ايمنى بيمار}

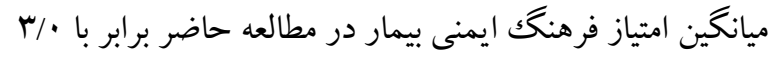

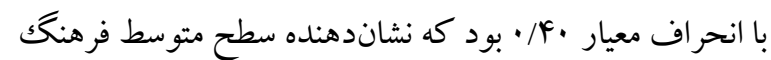
ايمنى بيمار است. از بين ابعاد فرهنگك ايمنى بيمار بيشترين ميانگين مربوط به بعد

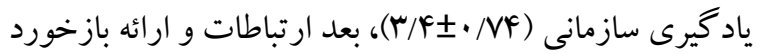

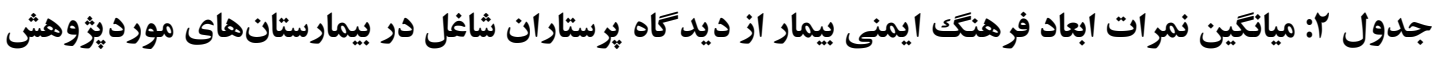

\begin{tabular}{|c|c|c|}
\hline انحر اف معيار & ميانكين & ابعاد فرهنك ايمنى بيمار \\
\hline$\cdot / V^{F}$ & $r / q$ & يادگيرى سازمانى \\
\hline$\cdot / A r$ & $r / f$ & ارتباطات و ارائه بازخورد در مورد خطاها \\
\hline$\cdot / M$ & $r / f$ & كار تيمى درون واحدهاى سازمانى \\
\hline$\cdot / V^{F}$ & $r / 1$ & حمايت مديريت از كار كنان \\
\hline$\cdot / A r$ & $r / 1$ & تناوب گزارش دهى رخداد \\
\hline$\cdot / 94$ & $r / 1$ & بِاسخ غير تنبيهى در قبال رويداد خطا \\
\hline$\cdot / \sqrt{ } 9$ & $\mu /$. & مسائل مربوط به كار كنان \\
\hline$\cdot / 91$ & $\mu /$ & كار تيمى بين واحدهاى سازمانى \\
\hline$\cdot 109$ & $\mu / \cdot$ & درك كلى از ايمنى بيمار \\
\hline$\cdot / N$ & $r / 9$ & 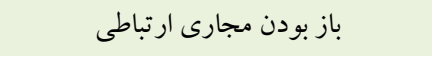 \\
\hline$\cdot 190$ & $r / 9$ & حمايت مديريت از ايمنى بيمار \\
\hline$\cdot / 19$ & $r / F$ & تبادلات و انتقال اطلاعات \\
\hline$\cdot / 4$ & $\mu / \cdot$ & ايمنى كلى بيمار \\
\hline
\end{tabular}

نكردهاند. همجنين، اكثر يرستاران (9F/9 درصد) مورد سقوط را در يكك سال گذشته بهصورت هر گز گزارش كردند. از طرف ديخر، بيشتر شر كت كنند گان مطالعه اظهار كردند كه در يكك سال گذشته هر گز تجربه مشاهده عوارض جانبى دارو (اه اله درصد)، عفونت زخم جراحى (ه// اله درصد)، واكنش به تزريق يا انتقال خون (Y/Yه درصد) و شكايت بيمار يا خانو ادهها ( FN/1)
وضعيت فرهنغك ايمنى بيمار در بخش و بيمارستان بهطوركلى ميانگين امتياز وضعيت فرهنگك ايمنى بيمار از ديدكاه يرستاران بر اساس ياسخ آنها به دو سؤال در مورد وضعيت كلى ايمنى بيمار در بخش و بيمارستان به ترتيب r/VF

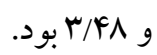

\section{حوادث ناخواسته}

بيشترين تعداد شركت كنند كان ( FN/1 درصد) عنوان كردند كه در طول يك سال كذشته هرگز زخم بستر مشاهده 
رابطه فرهنغَ ايمنى بيمار...

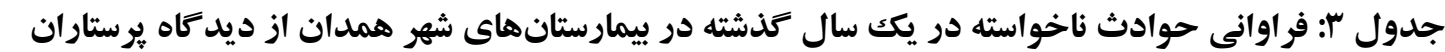

\begin{tabular}{|c|c|c|c|c|c|c|c|}
\hline هروز & جار در & يكتبار در & جار در ماه & يكبار در & جر سال بار & هر كز & \\
\hline $1(\% / \%)$ & $f(\% / / \Delta)$ & $r(\% / / r)$ & $1 f(\% / \Delta / f)$ & $r \cdot(\% / v / V)$ & $9 \pi(\% / \% \Delta / \Lambda)$ & $T r \Delta(/ F N / I)$ & زخم بستر \\
\hline $1(\% \cdot \%)$ & $1(\% \cdot / 4)$ & $r(\% \cdot / \Lambda)$ & $V(\% / r / V)$ & $r \mu(/ / N / \Lambda)$ & $\Delta \wedge(\% / r Y / \Gamma)$ & $19 \Lambda(1.94 / 9)$ & سقوط از تخت \\
\hline $1(\% / \%)$ & $1(\% \cdot / 4)$ & $1(\% \cdot / 4)$ & $v(\% / r / V)$ & $Y(\% / N / 1)$ & $9 \Delta(/ / \% 9 / \Delta)$ & $1 \% \Delta(/ . \Delta 1 / q)$ & عوارض جانبى دارو \\
\hline
\end{tabular}

جدول "ז: (ادامه)

\begin{tabular}{|c|c|c|c|c|c|c|c|}
\hline هروز - & جار درين & يكتبار در & جار در ماه & يكتبار در & جر سال بار & هركز & \\
\hline $1(\% / \%)$ & $1(\% / 4)$ & $r(\% / r)$ & $10(\% / . / 1)$ & $\Gamma(/ / N / \Lambda)$ & $\Delta r(/ / \Gamma / q)$ & $\operatorname{lnf}(/ . \Delta \mathrm{D} / \Delta)$ & عفونت زخم جراحى \\
\hline $1(\% \cdot / 4)$ & $1(\% \cdot / 4)$ & $r(\% \cdot / \Lambda)$ & $F(\% / / \Delta)$ & $r \Delta(/ / 9 / 9)$ & $V r(/ . Y N / 1)$ & $1 \Delta F(/ . \Delta Q / Y)$ & واكنش به تزريق يا انتقال خون \\
\hline $1(\% \cdot / 4)$ & $\wedge(\% / \Gamma / 1)$ & $r(\% 1 / r)$ & $Y F(\% / / \Gamma)$ & $10(\% / \Delta / \Lambda)$ & Af $(/ / \Gamma Y / \Gamma)$ & $\mid r \Delta(\% F N / 1)$ & شكايت بيماران يا خانواده \\
\hline
\end{tabular}

ايمنى بيمار و تمامى حوادث ناخواسته ارتباط معنادار وجود

رابطه بين ابعاد فرهنك ايمنى بيمار و حوادث

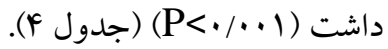
ناخواسته با كنترل متغيرهاى جمعيت شناختى يرستاران و ساير متغيرها

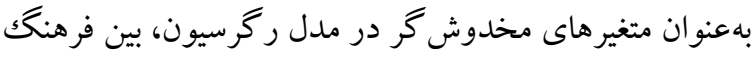

جدول ع: ركر سيون لجستيك رابطه بين ابعاد فرهنك ايمنى بيمار و حوادث ناخواسته در يك سال كذشته در

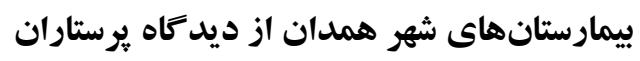

\begin{tabular}{|c|c|c|c|}
\hline P-value & 95\% CI & ضريب مدل ركرسيون (B) & متغير ها \\
\hline $\mathrm{P}<\cdot / \cdot \cdot 1$ & $(\cdot /$ YYG-・/FAI) & $\cdot / r Y q$ & 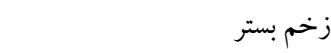 \\
\hline $\mathrm{P}<\cdot / \cdot \cdot 1$ & $\left(\cdot / r \Gamma_{\Lambda}-\cdot / \& ৭ q\right)$ & . /TFF & سقوط از تخت \\
\hline $\mathrm{P}<\cdot / \cdot \cdot 1$ & $(\cdot / r 9 \Lambda-\cdot / 9 \cdot 1)$ & - /4YG & عوارض جانبى دارو \\
\hline $\mathrm{P}<\cdot / \cdot \cdot 1$ & $(\cdot / r \mid r-\cdot / F \Delta Y)$ &. & عفونت زخم جراحى \\
\hline $\mathrm{P}<\cdot / \cdot \cdot 1$ & $\left(\cdot / r+\Delta \Delta_{-} \cdot / \& q 1\right)$ & $\cdot / \mu k$. & واكنش به تزريق يا انتقال خون \\
\hline $\mathrm{P}<\cdot / \cdot \cdot 1$ & $(\cdot / Y Y q-\cdot / F A F)$ & 每/ & شكايت بيماران يا خانو اده آنها \\
\hline
\end{tabular}

كه فرهنگ ايمنى بيمار در بيمارستانهاى موردمطالعه با

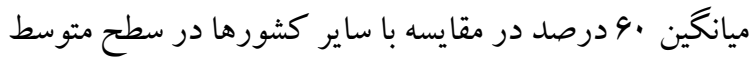
بحث قرار دارند. در ميان ابعاد مختلف مربوط به فرهنك ايمنى، مطالعه حاضر با هدف بررسى رابطه بين فرهنگك ايمنى بيمار و بالاترين امتياز مثبت به بعد كار تيمى درون واحدهاى

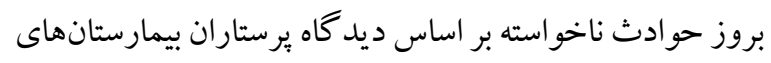

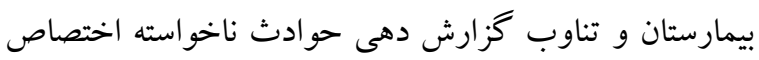
شهر همدان انجام شد.

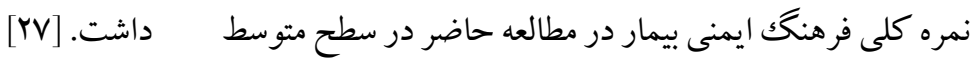

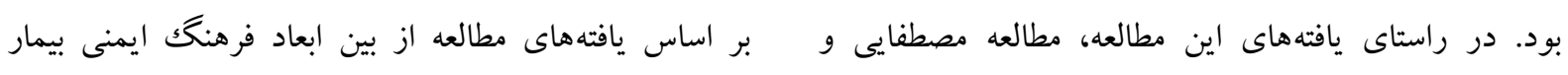

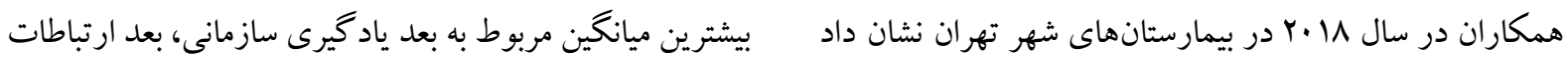


مديريت از ايمنى بيمار و كار كنان از نقاط ضعف فرهنگك ايمنى إنى

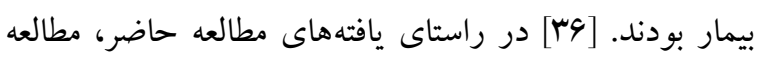

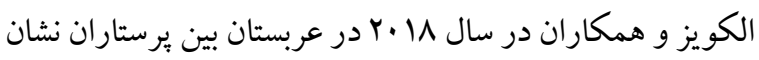

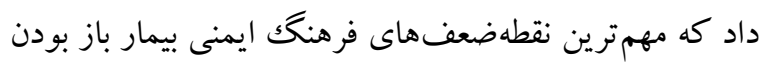

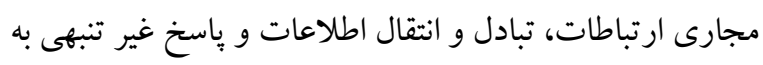

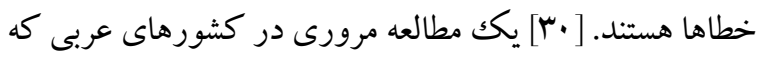

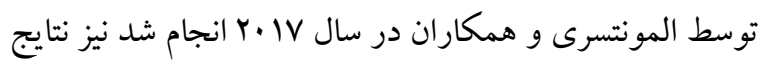

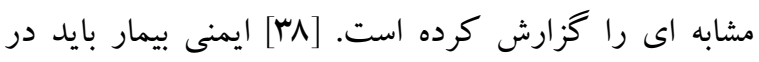

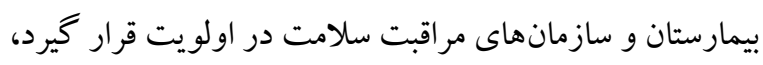

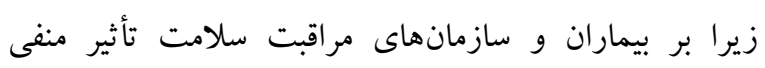

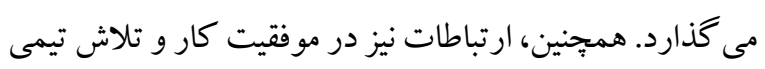
بهخصوص ميان كار كنان مراقبت سلامت ركن اصلى است.

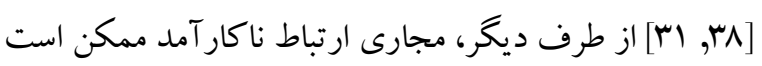

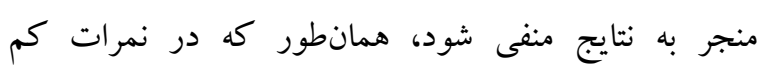

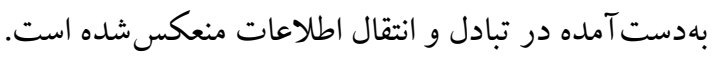
در مطالعه الجاردلى و همكاران [q"] در كشور لبنان در سال

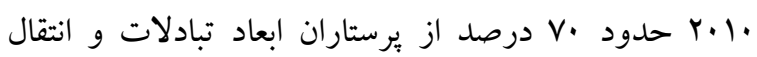

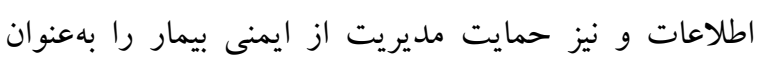

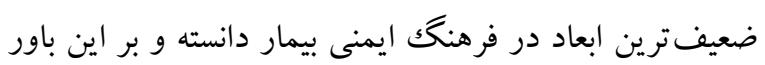

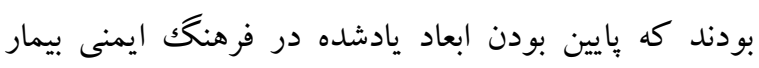

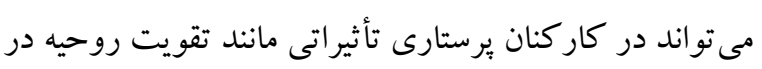

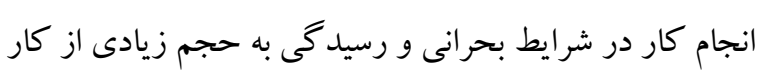

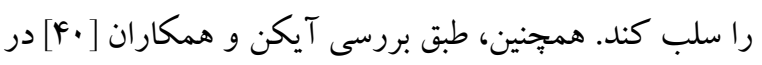

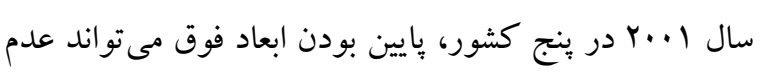

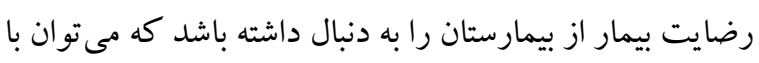

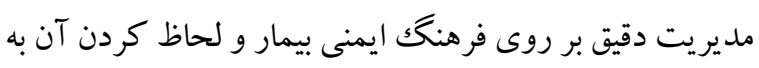
نحو احسن اين عامل را به بهترين سطح خود رساند.

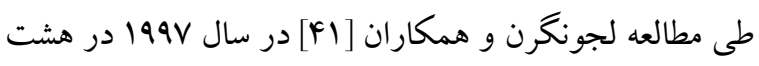

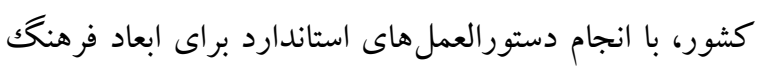

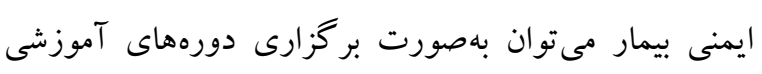

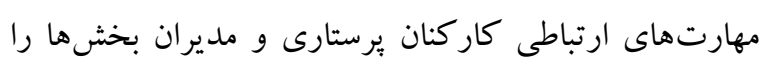

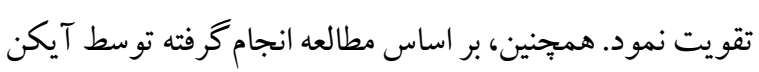

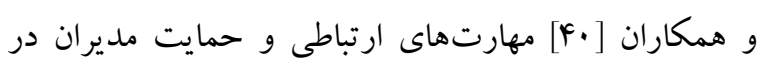

و ارائه بازخورد در مورد خطاها و كار تيمى درون واحدهاى

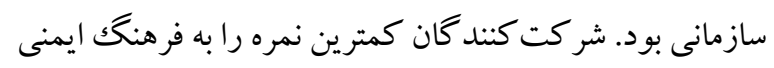

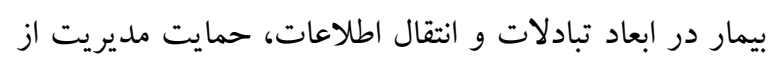
ايمنى بيمار و باز بودن مجارى ارتباطى داده بودند. در مطالعات

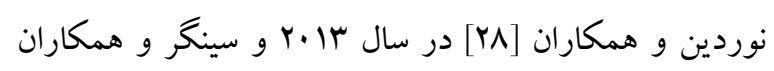

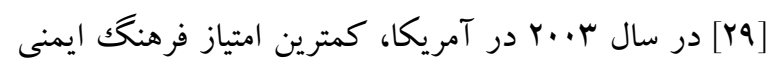
بيمار مربوط به عدم نظارت بشتيبانى مديريتى بر ايمنى بيمار إندار

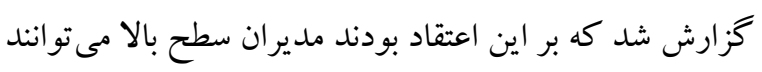

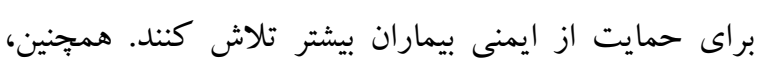

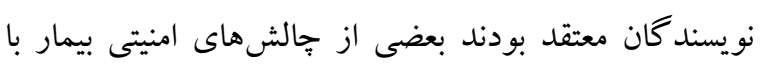

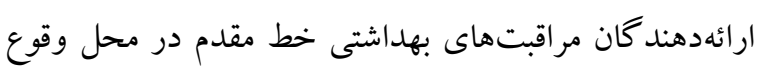

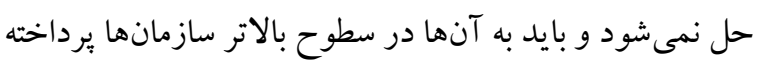
شود. در مطالعات انجامگرفته در كشورهاى ديخر مانند

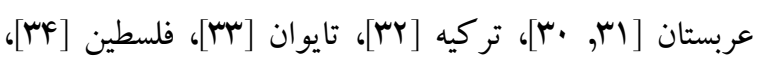

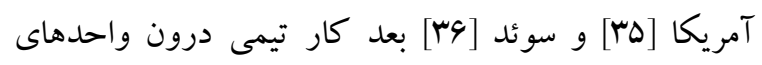

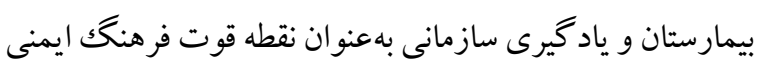

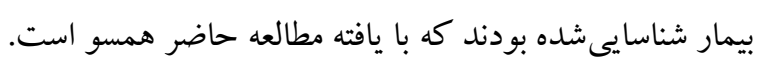

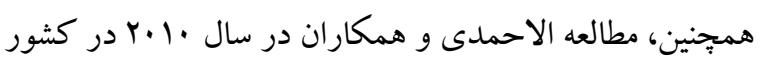

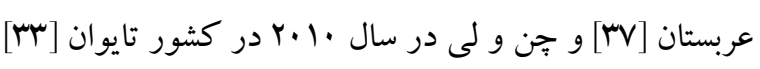
نشان داد كه از بين ابعاد فرهنگك ايمنى بيمار بالاترين ميانگين

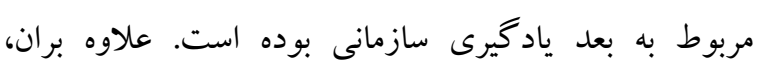

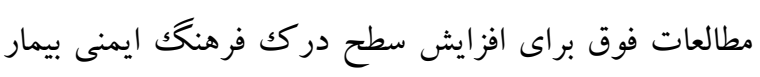

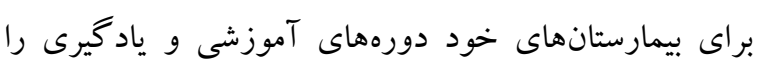
مدنظر قرار داده و بر اهميت كار گروهى تأكيد فراو ان داشتهاند.

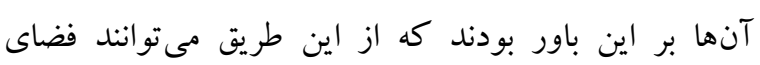
ياد گيرى و همكارى در سازمان و روحيه فرهنگ ايمنى بيماران

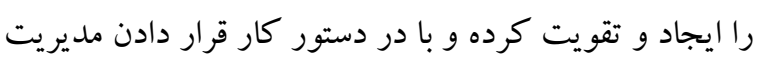

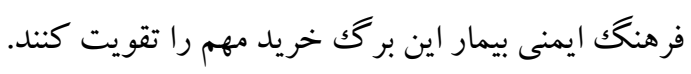
علاوه بر جند نقطه قوت اشارهشده در مطالعه، از ديدكاه

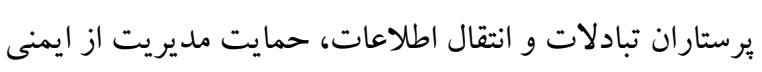
بيمار و باز بودن مجارى ارتباطى در بيمارستان بهعنوان

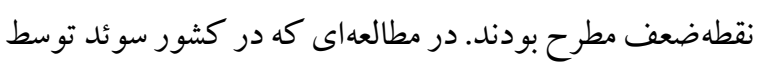
دنيلسون و همكاران در سال Y. V انجامشده است حمايت 
فرهنگ ايمنى بيمار ميزان بروز حوادث ناخواسته در بيمارستان

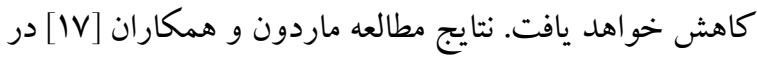

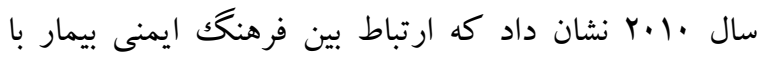

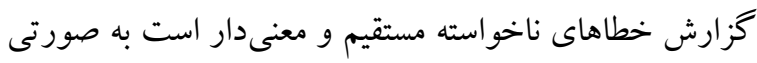
كه در بيمارستانهايى كه فرهنگك ايمنى بيمار بالاتر بوده، خطاهاى ناخواسته كمترى كزارش شده است. نتايج مطالعه نجار و همكاران [1] و فاروبٍ و همكاران [r] نشان داد كه ارتباط

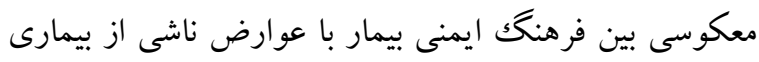

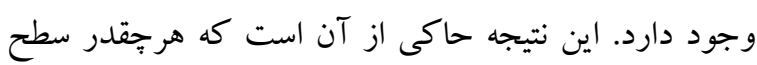

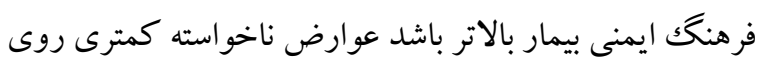
خواهد داد. لذا مسئو لان حوزه سلامت و بيمارستانها بايد در بـاني جهت ارتقاى فرهنك ايمنى بيمار در سيستم مديريت

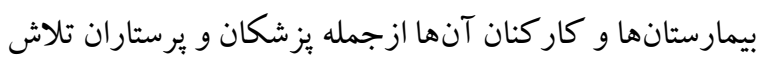
نمايند. نتايج مطالعه احمدى و همكاران در سال

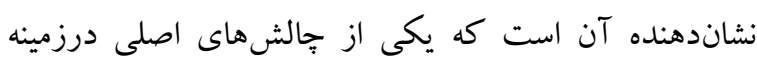
جالشهاى استقرار سيستم مديريت خطر در بيمارستانها نبود إندان

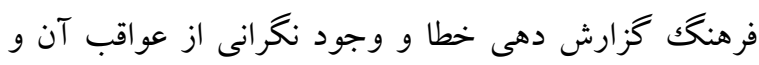

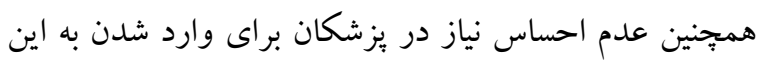

حيطه است. [Fr] مطالعات آينده مى تو انند درزمينه بررسى علل و عوامل مؤثر بر عملكرد ضعيف بيمارستان درزمينه گزارش دهى و و يا عدم كزارش موارد حوادث ناخواسته توسط كاركنان، صورت

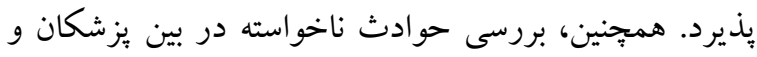
مقايسه آن با يرستاران نيز مىتواند در زمينه شناسايى ابعاد مختلف مؤثر بر كزارش دهى حوادث ناخواسته مفيد باشد.

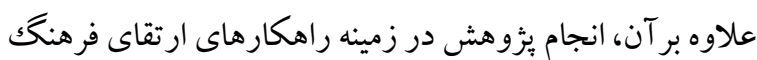

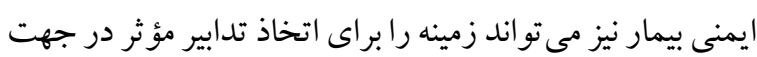

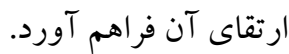
از آنجايى كه مطالعه حاضر بهصورت گذشتنهنگ انجامشده است و اطلاعات شركت كنند كان در مورد حو ادث ناخواسته در طول يكك سال كذشته استخراجشده است، يكى از محدوديت هاى

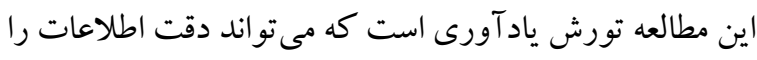

كشورهاى موردبررسى نظير (آمريكا /Fq درصد، كانادا Fr/F درصد و آلمان M/9 درصد) بوده است و با لحاظ سيستم

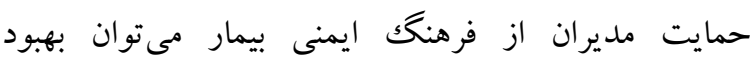
جشم گيرى در ابعاد فرهنگك ايمنى بيمار ايجاد كرد.

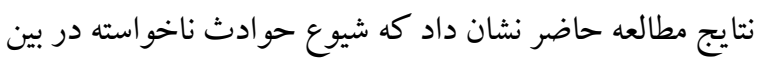

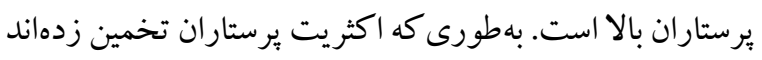
يككبار در سال حادثه ناخواسته براى آنها اتفاق افتاده است. ميزان گزارش حوادث ناخواسته در مطالعه عبادى و همكاران

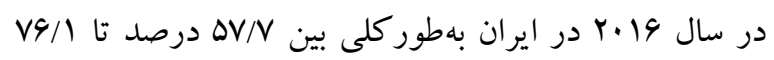
درصد بود و براى عفونت خون، زخم بستر، سقوط بيمار و

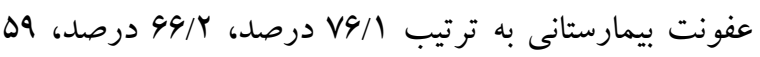
درصد و DV/V درصد گزارششده است. [V] در كشورهاى

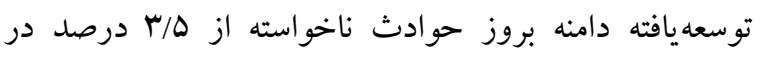

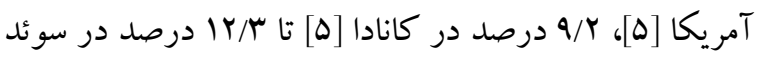

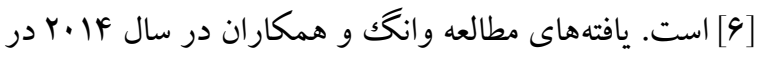

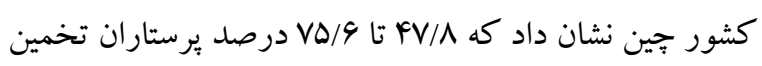
زدند كه در يكك سال كذشته حوادث ناخواسته مختلف برايشان

$$
\text { رخداده است. [19] درند }
$$
در برخى مطالعات انجامشده در اين زمينه كليه كادر درمانى بيمارستان را بهعنوان شر كت كننده در مطالعه وارد كرده بودند

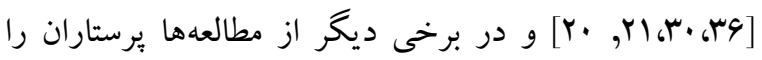

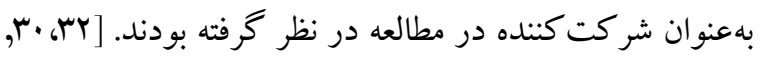
ع علت اين امر مىتواند تعداد بالاى برستاران نسبت به ساير

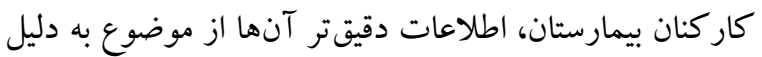
حضور بيشتر در بخش و ارتباط بيشتر با بيماران و همجنين

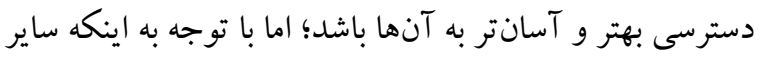
كروههاى كار كنان بيمارستان ازجمله يزشكان، بهياران، كادر خدماتى و ساير كار كنان بيمارستان كه در تماس مستقيم با بيمار

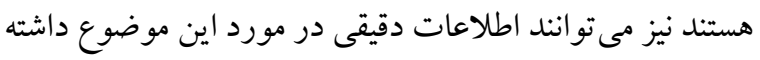
باشند، استفاده از اين گروهها در انجام يزٔوهش در اين زمينه در جمع آورى اطلاعات دقيقتر مؤثر خو اهد بود. بر اساس يافتهاى مطالعه حاضر فرهنگك ايمنى بيمار بيشبينى كننده معنى دار حوادث ناخواسته است. به اين معنى كه با بهبود 
براى گزارش دهى حوادث ناخواسته و برنامهريزى جهت كاهش اين حوادث را فراهم نمايند.

\section{ملاحظات اخلاقى}

رعايت دستورالعملهاى اخلاقى: اين يُزوهش با كد اخلاق به شماره IR.UMSHA.REC.1396.866 اخذشده از كميته اخلاق دانشگاه علوم يزشكى همدان

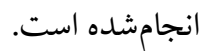

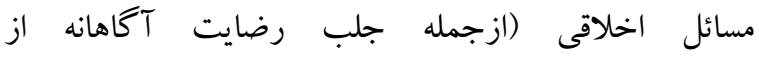
شر كت كنند گان، سرقت ادبى، انتشار / يا تسليم دو كانه و غيره) توسط نويسند كان بهطور كامل رعايت شده است. همجنين،

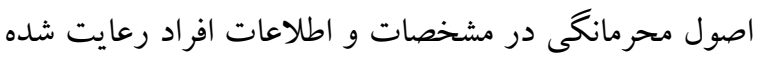

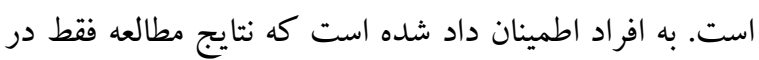

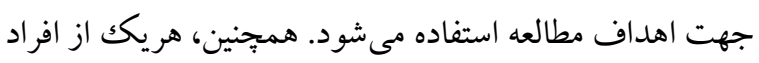

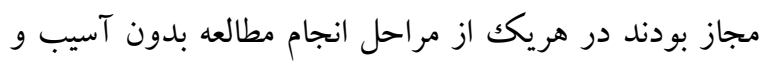
زيان مطالعه را ترك كنند. حمايت مالى: اين يزٔوهش با حمايت مالى دانشكاه علوم

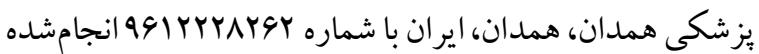

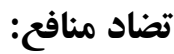

نويسند گان اظهار داشتند كه تضاد منافعى وجود ندارد. تشكر و قدردانى: اين مقاله حاصل بخشى از طرح تحقيقاتى

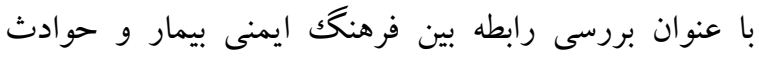
ناخواسته در بيمارستانهاى شهر همدان، مصوب معاونت تحقيقات و فن آورى دانشگاه علوم يزشكى همدان، در سال

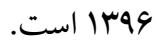
نويسندكان از معاونت تحقيقات و فن آورى دانشگاه علوم يز شكى همدان به خاطر تصويب و حمايت مالى از اين مطالعه

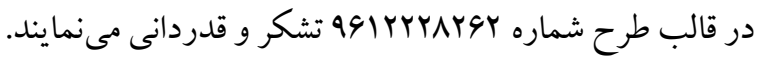
همجِنين، از كليه شركت كنند كان در مطالعه و مسئولين بيمارستانهاى موردمطالعه تشكر و قدردانى مىشود.
نمونه گيرى در دسترس است كه به دليل كاهش شانس حضور بخشى از كار كنان بيمارستان و حذف نظرات آنها، اين احتمال وجود دارد كه بخشى از اطلاعات ازدستر فته باشد. يكى ديخر از محدوديتهاى مطالعه حساسيت موجود در بيمارستانها

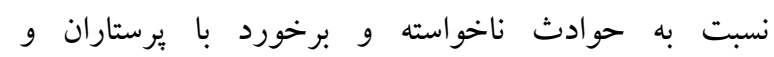

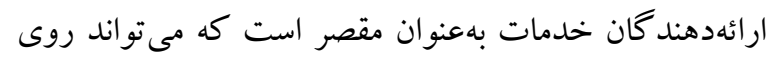
تمايل برستاران براى ارائه اين اطلاعات تأثير بحذارد.

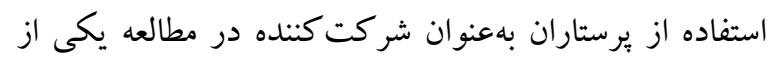
نقاط ضعف يزوهش حاضر است. درصورتى كه حضور ساير كار كنان بيمارستان كه با بيمار در تماس مستقيم هستند خصوصاً

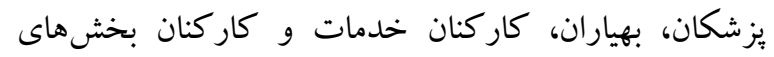
تشخيصى امكان استخراج اطلاعات دقيقتر در اين زمينه را

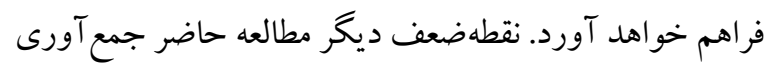
اطلاعات حوادث ناخواسته در قالب دو ززينه (مواجهه داشتن

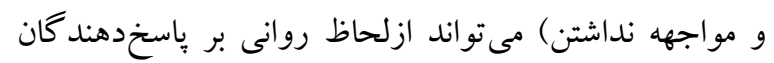

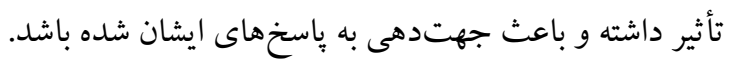

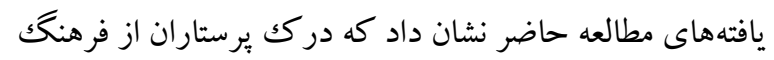

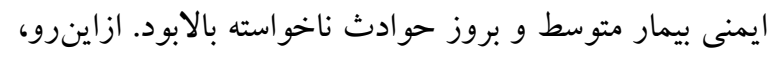
عواملى از قبيل حمايت مديران از ايمنى بيمار در بيمارستان،

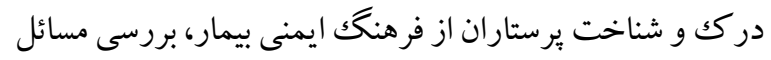
مربوط به كار كنان و تسهيل تبادل و انتقال اطلاعات در سازمان براى كاهش بروز حوادث ناخواسته ضرورى است. برگزارى كار كاههاى و دورههاى آموزشى در مورد فرهنك برون ايمنى بيمار براى مسئو لان و كار كنان بيمارستان مى تواند درزمينه ارتقاى

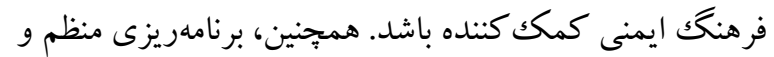
هدفمند در زمينه سنجش فرهنگك ايمنى بيمار و ارتقاى مداوم آن زمينه را براى ارتقاى فرهنگك ايمنى بيمار فراهم مى آورد. مطالعات بيشتر براى شناسايى مداخلاتى كه از طريق ارتقاى

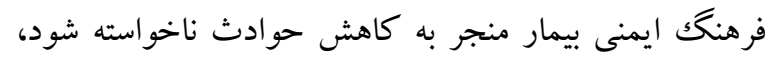
ضرورى به نظر مىرسد. از طرف ديخر متوليان سلامت بايد از طريق روشهايى مثل تشويق گزارش حوادث ناخواسته و

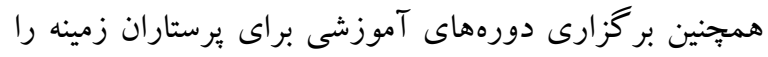


1. Asartmar M, Moqtada Mansouri A . The role of social responsibility components on organizational health, a case study of employees of Urmia Health Network. J Healthc Manage and Treat.2019;10(3): 7-21.[In Persian]

2. Taheri Nejadkani N, Tabibi SJ, Haji Nabi K. Relationship between hospital information system requirements and implementation of health system transformation plan in hospitals of Tehran University of Medical Sciences. Healthc Manage.2019; 8(1): 69-81.[ In Persian]

3. Dobrzykowski DD, McFadden KL, Vonderembse MA. Examining pathways to safety and financial performance in hospitals: A study of lean in professional service operations. J Oper Manage. 2016; $1 ; 42: 39-51$.

4. Ranjbar M, Bahrami M A, Baghanan N, Izadi R, Eftekhari A, Yousefzadeh S. Causes of selection of educational hospitals in Yazd city for treatment by patients in SL 1395. Health Manage.2019; 8(1):. 8191.[In Persian]

5. Kurdistani Gh, ghdarzadeh SK,Haghighat $\mathrm{H}$. The effect of revealing social responsibility on accounting, economic and market evaluation criteria of corporate performance. J Account Adv. 2018; 10(1):181-210. [In Persian]

6. Chang $\mathrm{YH}$, Yeh $\mathrm{CH}$. Corporate social responsibility and customer loyalty in intercity bus services. Transport policy. $2017 ; 1 ; 59: 38-45$.

7. Ja'faripuyan A, Pourreza A, Rahimi Forosani A,Maleki R. Assessment of the Importance and Status of Social Responsibility Implementation from the Perspective of Kermanshah University of Medical Sciences Educational Hospitals Management Network .Off $\mathrm{J}$ the Organ Hosp the Iran Assoc of Hosp Aff. 2018; 17(1):9-16.[ In Persian]

8. Droppert H, Bennett S. Corporate social responsibility in global health: an exploratory study of multinational pharmaceutical firms. Glob Health.2015;11(1):15.

9. Ghasemnejad Kh, JaziniA R, Mohammadi Moghaddam Y,Hendiani A.The Model of Corporate Social Responsibility in Social Crime Prevention. J Police Manage Res. 2019; 14 (1):9-32.[ In Persian]

10. McDaniel P A, Cadman B, Malone R E. African media coverage of tobacco industry corporate social responsibility initiatives. Glob public health. $2018 ; 1 ; 13(2): 43-129$.

11. Lubis AN. Corporate social responsibility in health sector: a case study in the government hospitals in Medan, Indonesia. Verslas: teorija ir praktika. 2018;19(1):25-36.

12. Pulker CE, Trapp GS, Scott JA, Pollard CM. Global supermarkets' corporate social responsibility commitments to public health: a content analysis. Glob and health. 2018;14(1):121.

13. Tripathi N, Bharadwaja M, Ghosh V, Kataki BB. CSR activities of a hospital: perspectives of stakeholders. Int J Bus Excellence. 2018;15(4):502-19.

14. Danaeifard H, Valavani S M, Azar A. Quantitative Research Methodology in Management: A Comprehensive Approach" by Saffar Publications. 2004.[ In Persian]

15. Naderi Bani M, Ebrahimzadeh Pezeshki R, Abolghasemi M, Malekinejad P. Designing a Conceptual Model for Achieving Organizational Entrepreneurship with a Combined Approach to Mikhailov's Fuzzy Hierarchical Analysis and Interpretive Structural Modeling (Case Study: Yazd Sports and Youth Organization). Appl Res in Sports Manage.2018; 23(3):127-139. [In Persian] 


$$
\text { على ازدرى و همكاران }
$$

16. Firoozjaeian A As, Firoozjaeian M, Hashemi Petroudi SH, Gholamrezazadeh F. Application of interpretive structural modeling technique in tourism studies(Analysis with a pathological approach). J Tourism Plann and Dev.2013; 6(2):129-159.[ In Persian]

17. Ismailpour R, Azar A, Shah Mohammadi M . Provide an interpretive structural model of supplier selection indicators based on corporate social responsibility J Ind Manage Stud.2017; 47(15):45-70.[ In Persian]

18.Cachon G, Swinney R. The value of fast fashion: quick response, enhanced design, and strategic consumer behavior. Manage Science . 2011;57 (4): 778-795.

19. Cekrezi A. Determinants of financial performance of the insurance companies: A case of Albania. Int $J$ Econ Commer and Manage. 2015;3(4):1-0.

20. Fatemi SA, Vahdat Sh, Hesam S .Designing a model for evaluating the performance of outsourcing services of Shahid Dr. Labbafi Nejad Hospital using a balanced evaluation card model. Health Manage. 2019; 10(1): 7-18.[ In Persian]

21. Adhami Moghadam F, Saheb Al-Zamani M, Rouhafza M. Investigating the gap between service quality from the perspective of hospitalized patients in hospitals of Islamic Azad University. Tehran Branch of Medical Sciences. 2019; 8(2) :21-32.[ In Persian] 